\title{
Several Points on Inheriting and Carry Forward Traditional Chinese Culture in the New Media Environment
}

\author{
Ling SUN \\ Shenyang University, Liaoning, China
}

\begin{abstract}
Inheriting and carrying forward traditional Chinese culture is of special significance and role for China's Socialist cultural construction in the new period. With the rapid development of science and technology and information, it is sensible to adopt diversified ways in order to achieve a subtle yet influential publicity. Beset by entanglement of the old and new media broadcasting, how to better take advantages of the two forms of media in order to promote propagandizing traditional Chinese culture is an important task before us.
\end{abstract}

KEYWORDS: new media; traditional culture; nation

The traditional culture of China is like a long river of more than 5,000 years, endless, successive and profound, with brilliant achievements in politics, economy, culture, art, history, philosophy, ethics, law and other fields, which is based on thousands of years of human wisdom and has made an important contribution to both the development of Chinese society and the evolution of mankind. In the new period, General Secretary Xi Jinping confirmed in a series of important speeches the necessity of inheriting and carrying forward the fine traditional Chinese culture, and affirmed the great value of excellent traditional Chinese culture in the Socialist cultural construction. The overland Silk Road during Han and Tang dynasties, and Maritime Silk Road of Song and Yuan dynasties of China witnessed the history of the friendly exchanges between China and the peoples of the world; the traditional Chinese virtues such as filial piety, patriotism, pioneering and enterprising spirit, as well as noble dignity, are our spiritual fruits passed on from generation to generation over thousands of years. As is said "looking around this word, the longevity of our nation and the greatness of the national scale is absolutely out of the few companions, is unrivalled in ancient and modern times." [1]

Inheriting and carrying forward traditional Chinese culture is of special significance and role for China's Socialist cultural construction in the new period. With the rapid development of science and technology and information, it is sensible to adopt diversified ways in order to achieve a subtle yet influential publicity. Traditional media, such as radio, television, newspapers, etc., for decades occupied the mainstream publicity position of State ideology, but the emergence and spread of new media, mainly the network, quickly brings China's media propaganda into the 3.0 era, continually impacting people's cognition and understanding toward traditional patterns of communication. Beset by entanglement of the old and new media broadcasting, how to better take advantage of the two forms of media in order to promote propagandizing traditional Chinese culture so as to put the historical heritage into the new era and contribute to improving China's cultural soft power is an important task before us.

\section{THE RISE OF THE STATUS AND ROLE OF NEW MEDIA SHOULD NOT BE NEGLECTED}

New media, a concept opposed to radio, television, newspapers and other traditional media, is developed after these traditional media, dominated by online media, toward a "triple play" direction of the Internet and cell phones and television. It has changed the traditional pattern of communication, with a subtle change of the three elements ensuing. The emergence of We Media is under such knock-on effects. We media is also named as "personal media" or "citizen media", which is more personal, democratized and self-determining compared with other forms of media, including BBS, blog, SNS, micro-blog, and Wechat, etc.. Due to the development of science and technology, cell phones 
have gradually replaced computers and become mainstream mobile Internet terminal equipment, based on which device controllers would create a small social network through the Internet, playing the function of social exchange and informative communication. The emergence of the Internet completely changes the passive status of traditional human as information receivers, and vocal freedom is liberated. New media is the necessity of social development and progress, as well as an inevitable evolution of history. China, in order to link with the world, could not reject the great influence of the Internet on human society. New media maximizes the involvement of everyone in the informative communication swirling, breaking the barriers and shorten the cycle of communication, sufficiently featuring interactivity of informative communication.

With the coexistence of old and new media in today's society, we are supposed to make good use of new media's influence and advantages on the basis of traditional media, using multiple communicative channels to promote disseminating traditional Chinese culture to put such idea into both people's minds and action. Excellent traditional Chinese culture is the foundation of the advanced Socialist culture and origin, hence the power source to realize the Chinese dream, whose profound achievements reflect in all aspects of social development, reflected in the course of long-term and arduous social practice and pioneering work. Along with social progress, the part of traditional culture serving directly the feudal economic foundation and political superstructure has been disavowed, and then disappears. While the numerous essence of traditional culture, especially the part tried and deposited during thousands of years that reflects the social productivity, the Chinese mentality and behavior, should be unconditionally preserved and handed down. Chinese system of etiquette, values, lifestyle and customs, etc. are the most valuable cultural heritage and wealth created by all ethnic groups, maintaining the cultural and psychological structure of national members. Traditional media has its long-term influences, large width of dissemination with the linear disseminating characteristics, and is important means of mainstream national values; new media is a collection of pictures, text and video, with its characteristics of diversity, universality and arbitrariness, hence needs deeply digging and governance. It is conducive to use diverse forms to show the fine traditional Chinese culture all around, to build a harmonious Socialist society, to promote the national progress and make our nation stand firm among the nations of the world.

\section{BREAKING THE MEDIA BARRIERS, OFFERING CONTENTS “TO THE GROUND”}

New media is a new disseminative modality accompanied by the progress of science and technology. In the perspective of social development process, it is in favor of the democratic and civil development and progress for both state and nation. Today's new media being in full swing, there should not be opposition or rivalry between old and new media, but be in mutual complement and integration, closer towards each other, utilizing their respective advantages to achieve more prominent disseminative results. Promoting awareness of traditional Chinese culture via media is an important part of Socialist cultural construction. Excellent traditional Chinese culture does exist in each one of us in real life, but is often neglected or even abandoned. In the new period, we need not only develop the Socialist economic construction, but also constantly enhance Chinese cultural soft power. Therefore, excellent traditional culture needs casting into socialist culture to explore the national characteristics that Chinese people prefer. Only in this way can Socialist culture be deeply rooted in people's hearts and form a kind of "cultural consciousness" and esteem of the harmony between man and nature, thus to create Chinese nation's new brilliance with the drive of new spirit of the times.

Traditional Chinese culture accumulated during 5,000 years is a crystallization of rational thoughts, which needs a transformation from rational to emotional course to eventually present before audiences through the media. "Spring snow" preaching is no longer sufficient to impress the audience, instead, the variation of disseminative forms and contents "to the ground" will really penetrate. So-called "to the ground" refers to starting with the real life, selecting the most familiar yet most easily overlooked tiny things as cut-in point, adopting flexible and changeable forms of creation (such as three-dimensional animation, Flash, and Micro, etc.), using the advantages of new media network spreading channel so that the masses of people understand and perceive the meaning and value of excellent traditional Chinese culture from details of life. Among traditional media, whether TV or radio, "public topics", "the welfare show", and "public service advertisement", etc. are an important means of spreading excellent traditional Chinese culture. Under the new media environment, disseminative forms have changed a lot: people surfing the Internet, updating micro-blogs, following Wechat public accounts. Media get much closer to the public as the contents of dissemination get closer to life. The better way is to originate from reality and reflecting great via tiny. Taking public morality for example, it is undeniable that in today's China public morality remains to be strengthened. China is 
well known for its rites and etiquettes, "guiding with morals", "controlling with proprieties" and "pursuing faith and harmony", etc. are all excellent thoughts from Chinese tradition. But the present society is filled with trapping, hoodwinking, abducting, cheating and stealing events, retreading and sometimes even abominable; the act of faking, injury feigning for compensation and abandoning wives are of common occurrence. Therefore Faith Construction is a burning issue for China today. To solve this problem, personal discipline is necessary to be proceeded, with the aid of new media, as now Wechat public accounts do, as well as some excellent short articles, micro-dramas integrated with traditional Chinese culture, taking history as a guide, calling on the public to create an open and honest social attitudes, thereby strengthening the moral construction and establishing Socialist core values.

\section{TWO CONVERGENCES AND ONE INNOVATION}

The two convergences refer to the convergence between old and new media and the convergence between East and West. The former has been discussed in the above paragraphs, hence there is no sense dwelling on more details. Objectively speaking, the battle between old and new media is an inevitable social problem, as whichever new things rise would endanger the developing patterns of the old. But from the angle of subjective practice, we media staff should have great vision and great outlook. The future social development is inseparable from the network; ignoring network means condemning our future. Therefore, the future development trend should be the convergence of old and new media, which is not simply the copying or imitating in form but a new look both in form and content, and this requires innovation and a benign social environment. The convergence between East and West refers to absorb foreign cultures to carry forward traditional Chinese culture. "Only by combining inheriting profound tradition cultural and absorbing as much as possible as well as being boldly open, can we better exert the advantages in the surge of different cultures and thoughts in the world and bring Socialist culture prosperity and development." [2] The development of new media offers a better chance for cultural exchange and a smoother platform. Of course, the premise of using new media to promote the convergence between Eastern and Western culture is strict regulation on web platform. Additionally, promoting cultural convergence needs to be rooted in excellent national culture, insisting principles of "I priority" and "making foreign serve native", selecting conducive and excellent Western culture, firmly rejecting tendencies of worshiping and fawning on the foreign, swallowing anything immoderately, and blind imitation, and to digest and transform Western culture from the angle of internationalization for the purpose of creative absorption.

One innovation refers to innovative ideas and creative ways of thinking in the new period, whether in absorbing Western cultures or inheriting the traditional. For our nation, it is not the ultimate objective to hand down the culture, but to let the culture veritably serve, adapting to the changes of times and international environment to fully materialize its intrinsic value and significance. In addition, excellent traditional culture needs to go abroad to stand on the international stage and present the broad mind and profundity of Chinese nation. In the new period, media contact is no longer the patent of professionals; the popularity of the web platform is beneficial to stimulating civil innovative flash of ideas, to inspiring the general public to participate in the State and national building to create outstanding achievements of human civilization. For example, the network collected works is a very common form: it is a dynamic way not only to increase influence but also to arouse the public enthusiasm, and to aggregate folk wisdom to create innovative and more grounded works. Taking this as a guide, promoting traditional Chinese culture can completely depend on the power and advantages of new media, and involve ordinary people in disseminative activities and the subtle influence, eventually resulting in cultural consciousness and indirectly molding benign cultural environment.

"The value of traditional Chinese culture is the emphasis on faith and ethics, in which individuals can find 'ultimate concern' towards life." [3] Inheritance and development of traditional Chinese culture is of great significance to the social development, as well as to the harmonious coexistence between China and other countries. In the new period of media development, rationally utilizing advantages and characteristics of both old and new media and adopting various forms to disseminate will accomplish a social faith in respecting history, esteeming learning and honoring culture. With such a stable power, people of faith will interiorly regulate and restrict themselves, thereby create the civilization and progress of the whole nation.

\section{REFERENCES}

[1] Qian, Mu. The Outline of National History (revised edition). Beijing: Commercial Press, 1996:45.

[2] Xu,Yiying. Carrying forward the Fine Traditional Culture. the Masses, 2001.11:47.

[3] Xue, Cheng. Inheriting and Carrying forward Traditional Chinese Culture in the Open Exchanges and Peaceful Interaction . Reader, 2014.3 (355): 5. 
[4] Wang, Fei. Media Convergence: On Media Convergence in New Digital Media Age. Guangdong: Nanfang Daily Press, 2007.5.

[5] Lu, Xiaohua. New Media Concept: Mode of Thinking in the Age of Informative Survival. Beijing: Tsinghua
University Press, 2008.10.

[6] Zhang, Qizhi. Scientifically Treating the Traditional Culture. Qiushi, 1995.11.

[7] Yang, Jihong. Who Is The New Media. Beijing: Tsinghua University Press, 2008.10 